(4)

\title{
磁気レンズを用いた中性子線の制御技術 とその応用*
}

Magnetic Neutron Optics and Its Applications

\section{清水裕彦** \\ Hirohiko SHIMIZU}

Key words slow neutron, neutron optics, neutron science, magnetic lens, small angle neutron scattering

\section{1. 中性子光 学}

運動エネルギーが $1 \mathrm{eV}$ 以下の中性子は低速中性子と呼 ばれる。科学研究や産業に利用される中性子ビームの大半 は低速中性子ビームである ${ }^{* 1}$. 中性子ビームの制御に利用 される相互作用は, 強い相互作用, 電磁相互作用, 重力相 互作用である。

低速中性子の波長は原子核の大きさよりもはるかに長 く, 原子の大きさと同程度あるいはそれよりも長いた め*2, 強い相互作用の効果は, 原子核のポテンシャルを原 子体積で平均したポテンシャルで記述できる。このポテン シャルは擬フェルミポテンシャルと呼ばれ, 中性子質量を $m_{n}$, 中性子散乱長を $b$, 核数密度を $N$ とするとき, $U_{\text {nucl }}=\left(2 \pi \hbar^{2} / m_{n}\right) b N$ で与えられる. 固体の擬フェルミポ テンシャルは $U \sim 10^{-7} \mathrm{eV}$ のオーダーである. 物質の界面 などには擬フェルミポテンシャルに差があることが多く， 中性子はその界面において反射および屈折される。

中性子は電荷をもたないため, 電磁相互作用の主要項は 磁気双極子能率 $\mu_{n}$ と磁場 $B$ の相互作用であり, そのポテ ンシャルは $U_{\mathrm{EM}}=-\mu_{n} \cdot \boldsymbol{B}$ で与えられる. 中性子スピンに 平行な単位べクトルを $\sigma_{n}$ として, $\mu_{n}=-\left|\mu_{n}\right| \sigma_{n}$ とおくと き, $\left|\mu_{n}\right|=60.3\left[\mathrm{neV} \mathrm{T}^{-1}\right]$ である. よって $1 \mathrm{~T}$ の磁場下で, スピンが磁場に平行な場合と反平行な場合のポテンシャル エネルギーの差は $120 \mathrm{neV}$ である.

重力相互作用は, 地球による重力を考慮すれば十分であ る. 鉛直方向に $h$ だけ中性子をもち上げたときに得る位 置エネルギーを $U_{g}$ とすると, $U_{g} / h=103\left[\mathrm{neV} \mathrm{m}^{-1}\right]$ である.

さて, 低速中性子は運動エネルギーによって図 1 に示 したように区分される.中性子の運動を制御する相互作用 は, 超冷中性子であれば運動に大きな影響を与え, どのよ うな角度で入射した中性子でも反射することが可能にな る. これを利用して, 物質容器や勾配磁場に中性子を蓄積 することが可能であり, 素粒子物理学の研究で用いられる

*原稿受付 平成 25 年 7 月 8 日

**名古屋大学大学院理学研究科 (名古屋市千種区不老町)
ことが多い.しかし物質の媣部に侵入することがないた め, 物質研究への利用は極めて限定的である. 物質研究に は, 極冷中性子, 冷中性子, 熱中性子が利用される。相互 作用の影響はこの順番に小さくなり，一般に中性子光学は 弱い光学系となる*3. 以下, 磁気相互作用を用いた中性子 光学の一部について, 概要を示す.

\section{2. 磁気光学系}

磁場 $B$ 中の中性子の運動は, 次の連立微分方程式で記 述される。

$$
\frac{d^{2} \boldsymbol{r}}{d t^{2}}=-\alpha \nabla\left(\boldsymbol{\sigma}_{n} \cdot \boldsymbol{B}\right), \quad \frac{d \boldsymbol{\sigma}_{n}}{d t}=-\gamma_{n} \boldsymbol{\sigma}_{n} \times \boldsymbol{B}
$$

ここで, $\sigma_{n}$ は中性子スピンに平行な単位べクトル, $\alpha=\left|\mu_{n} / m_{n}\right|=5.768 \mathrm{~m}^{2} \quad \mathrm{~s}^{-2} \quad \mathrm{~T}^{-1}, \quad \gamma_{n}=2\left|\mu_{n}\right| / \hbar=1.83 \times 10^{8}$ $\left[\mathrm{rad} \mathrm{s}^{-1} \mathrm{~T}^{-1}\right]$ は中性子の磁気回転比である. 中性子スピン は磁場中では磁場の方向を軸として角振動数 $\omega_{\mathrm{L}}=\gamma_{n}|\boldsymbol{B}|$ の Larmor 歳差運動をする一方, 磁場の方向が一定でない 場合には, 中性子とともに動く座標系から見ると磁場が回 転する，中性子から見た磁場の回転角振動数を $\omega_{\mathrm{B}}$ とおく と, 中性子の軌道に沿った座標を $s$ とするとき, $\omega_{\mathrm{B}}=v_{n}|\partial(\boldsymbol{B} /|\boldsymbol{B}|) / \partial s|$ である.ここで, $\Gamma=\omega_{\mathrm{L}} / \omega_{\mathrm{B}}$ と扔く. $\Gamma$ が1に比べて十分大きい場合には, 中性子スピンの磁場

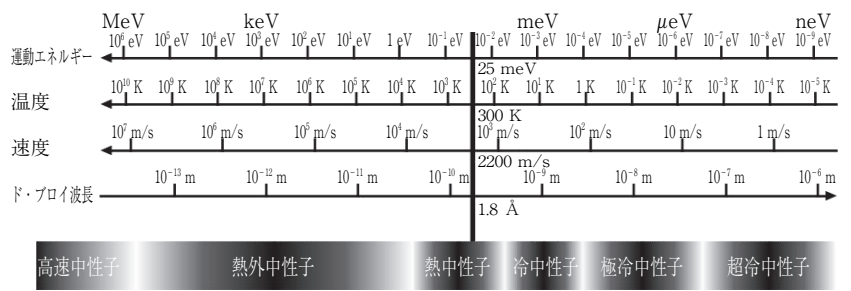

図 1 運動エネルギー領域ごとの中性子の名称

*1 $1 \mathrm{eV}=1.6 \times 10^{-19} \mathrm{~J}$

*2 中性子の運動エネルギーを $E_{n}$, 温度を $T_{n}$, 速度を $v_{n}$, 波長を $\lambda_{n}$ とす るとき, $E_{n} / 25[\mathrm{meV}]=T_{n} / 300[\mathrm{~K}]=\left[v_{n} / 2200[\mathrm{~m} / \mathrm{s}]\right]^{2}=\left[0.18[\mathrm{~nm}] / \lambda_{n}\right]^{2}$ で ある。

*3 中性子波動の干渉を用いれば, 相互作用が小さくとも大きな角度に中 性子の運動を変更することが可能であり, 回折光学と呼ばれる。単結晶 や回折格子が用いられる。 
に対する相対的な向きはほぼ固定される ${ }^{1)}$.このとき，上 記の連立微分方程式は次のように単純になる。

$$
\frac{d^{2} \boldsymbol{r}}{d t^{2}}=\mp \alpha \nabla|\boldsymbol{B}|
$$

ただし，複号は，負が中性子スピンが磁場に平行な場合， 正が中性子スピンが磁場に反平行な場合に対応する。磁場 に非偏極の中性子が入射する場合には，半数が平行，その 他の半数が反平行として，それぞれが対応する運動方程式 に従うものとして扱うことができる。低速中性子に対して は，「は1よりも十分に大きくなることが多く，式(2)を 用いることで, 磁場の測定精度の範囲に执いて中性子の軌 道を正確に計算できるという点が磁気光学系の特徵である.

さて，六極磁場の場合には， $|\boldsymbol{B}|=(G / 2)\left(x^{2}+y^{2}\right)$ と書け る. $\omega^{2}=\alpha G$ とおくと運動方程式は

$$
\frac{d^{2} x}{d t^{2}}=\mp \omega^{2} x, \quad \frac{d^{2} y}{d t^{2}}=\mp \omega^{2} y
$$

となり，スピンが局所磁場に平行な成分は磁石の軸に対し て単振動する。点中性子源を六極磁石の入口に置いたとき は， $\omega t=\pi$ が満たされる場所に収束される，反平行の成分 は磁石の軸から離されていき，磁石内壁などにあたって失 われる。 その結果，中性子のレンズとして機能させること ができる2)。そして，収束された中性子はスピンが偏極し ている，以下，このような光学系を磁気レンズと呼ぶこと にする。

なお，中性子が磁気レンズで収束される点の位置は，中 性子が磁場中に滞在する時間に依存して変化するので，中 性子速度に依存する。すなわち，磁気レンズは色収差をも つ．中性子速度に関わらずに焦点の位置を一定に保つため には，この色収差を相殺する必要がある。

\section{3. 集光型中性子小角散乱}

試料によって中性子が散乱されるとき，入射中性子およ び散乱中性子の波数べクトルをそれぞれ $k ， k^{\prime}$ と抄き，移 行波数べクトルを $\boldsymbol{q}=\boldsymbol{k}^{\prime}-\boldsymbol{k}$ で定義する. 中性子の散乱角 を $\theta$ とし， $k=|\boldsymbol{k}|$ とすると，弾性散乱の場合には $q=|\boldsymbol{q}|=2 k \sin \theta / 2$ である. 散乱中性子の強度を移行波数 $q$ の関数として表したものを $I(q)$ と書くことにする。こ の $I(q)$ の最低次は, 散乱長密度を $\rho(\boldsymbol{r})$ とするとき, $I(q)=\left|\int_{V} \rho(\boldsymbol{r}) e^{i \boldsymbol{q} \cdot \boldsymbol{r}} d \boldsymbol{r}\right|^{2}$ で与えられ, $q^{-1}$ 程度の空間スケー ルの構造が観測できることが分かる，小角散乱とは，概ね $q \leq 1 \mathrm{~nm}^{-1}$ の領域での $I(q)$ の測定を行うことを指し， 1 $\mathrm{nm}$ 以上のメゾスケールの構造を調べる手段である. $k=10 \mathrm{~nm}^{-1}$ 程度の冷中性子を用いる場合には, 散乱角は $\theta<0.1 \mathrm{rad}$ 程度であり，前方散乱を観測することに対応す る。より大きな空間スケールでの構造を観測するために は，より小さな角度での散乱を観測することが求められる ので, 計測可能な $q$ の最小值 $q_{\min }$ は小角散乱装置を特徵 付ける重要なパラメータである。

中性子の散乱角を決定するためには，入射ビームの平行

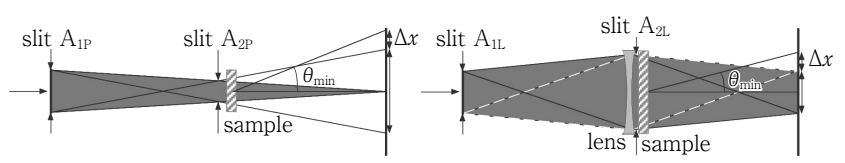

図 2 従来型小角散乱（左）と集光型小角散乱（右）の概念図

性を確保する必要がある，以前は図 2 (左) に示すよう に，二つのスリットを用いて，平行な中性子だけを試料に 当てるようにしていた。この方法では，試料で散乱されな かった中性子ビームは，焦点面上に半影を伴う像を結ぶ. この直接ビームの像の大きさが $q_{\min } \sim k \theta_{\min }$ を決める。 そ れは, 直接ビームは強度が高く検出器が計数できる範囲を 超えるために，通常は直接ビームを遮弊する必要があるか らである。これは検出器を高性能化することで解決する可 能性があるが，直接ビームの半影領域に含まれる散乱中性 子成分を同定するためには，余分に統計精度を高める必要 から計測時間が長くなる，デー夕処理が多少複雑化するな どの問題を伴い，一般に好まれない．

そこで集光型の中性子小角散乱が考案され, 現在の中性 子小角散乱は集光機能をもつものが主流になりつつある. 集光型小角散乱の概念を図 2 (右) に示す。スリットで定 義された発散ビームを検出器面に対してレンズで集光し, レンズと検出器面の間に試料を置く. 直接ビームの像に半 影が伴わないので，小さな角度での散乱を同定しやすくな る。ささらに, 発散ビームを全て検出器面に導くので, レン ズの口径が許す限り統計精度を向上させることが可能で, 計測時間の短縮につながる。 また, 検出器の位置分解能が 高ければ，試料と検出器面の距離を短縮することが可能で あり，装置全体を小型化することができる，それは同時に 同じ大きさの装置で， $q_{\min }$ を小さくしたり， $q$ 分解能を向 上させることが可能だということを意味する，従来型小角 散乱では, 直接ビーム像の大きさが, 達成可能な検出器の 位置分解能よりも大きかったため, 集光機能を搭載するこ とで装置の小型化或は高性能化が可能であった。従来は中 性子小角散乱装置は全長 $40 \mathrm{~m}$ に及ぶものであったが，同 程度の性能は数 $\mathrm{m}$ で達成可能になった。

集光レンズには，曲面ミラーを用いた反射光学系，物質 界面での屈折を利用した物質レンズ，磁気レンズが用いられ る. 曲面ミラーは大きな反射臨界角と形状精度, 物質レンズ

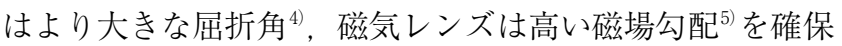
することが求められる，またどの場合も，本来の直接ビーム 像の外側に達する非散乱中性子を抑制することが求められ る.

曲面ミラーは精密加工技術に支えられて表面粗さを抑制 することで高性能化が図られている.

物質レンズには，厚いレンズを積み重ねたものが実際に は利用されている。物質レンズの屈折角は，フレネル形状 の薄いレンズを積層することで屈折角を大きくすることが できるが4)，フレネル形状のバックカットによる不要な屈 折㧍よび反射が伴うため，小角散乱の主光学系には用いら 
れていない。フレネル形状の物質レンズは，大きな偏向角 が優先する場面で応用されると考えられる.

磁気レンズの場合は，レンズに入射する中性子のスピン 偏極度を高め, 集光されないスピン状態を排除することで 高性能化が図られている ${ }^{3)}$. 現在では, 十分に高い偏極度 が問題なく達成されるようになっている。磁気レンズ系は 正確に結像するという特性があるため, 高性能小角散乱を 実現するものと見込める. 特に, 偏極中性子が用いられる ので, メゾスケールでの磁気的な構造の研究でユニークな 研究領域を形成すると見込まれる。

このような集光光学系の利用が進んだ結果, 国内の定常 中性子源を用いた中性子小角散乱装置には, 物質レンズお よび磁気レンズが搭載されている67).

\section{4. パルス中性子の磁気集光型小角散乱}

磁気光学系は色収差を伴うため, パルス中性子ビームを 用いた小角散乱を実行するためには, 色収差を相殺する必 要がある。パルス中性子源から離れた位置で待ち構えてい ると, 速度の大きな中性子がまず到着し, 徐々に, より遅 い中性子が到着する。よって, 中性子の発生時刻から, 徐々に磁気レンズの集束力を弱めると，色収差を相殺でき る. 色収差の相殺のために，これまでに二つの方法が開発 されてきた。

その一つは, 磁気レンズを複数に分割し, その途中にス ピン反転器を挿入するというものである ${ }^{8)}$. 磁気レンズ は, 局所磁場に対して中性子スピンが正極性なのか負極性 なのかで収束および発散レンズとして機能する。そこで, 中性子時刻に同期して, ある時間幅でスピン反転器を動作 させると, 近似的に色収差を相殺できる。これによって計 測に使用する速度範囲で, 実用上問題のない程度に色収差 を相殺することが可能である。

もう一つは, 中性子の飛行時間に同期して磁気レンズの 強度を変調させることで, 焦点距離を一定に保つというも のである ${ }^{9)}$. 連続的に磁気レンズの強度を変化させること ができれば，ほぼ完全に色収差を相殺できる，強度を変調 できる永久六極磁石の開発により，この方法が実証されて いる. この六極磁石は, 軸を同じくする二つの六極磁石に よって構成されており, 両者を相対的に回転させると, そ れぞれが発生する磁場が中心軸付近で強めあったり弱めあ ったりする。そこで，その回転を中性子飛行時間に同期さ せれば色収差が相殺される。このような磁気レンズを, こ こでは，回転六極磁気レンズと呼ぶことにする。

このような回転六極磁気レンズを用いることで, 中性子 飛行時間と同期した集光型小角散乱計測が実証されている （図 3)，その実証実験では，極冷中性子が用いられてい る. 極冷中性子が得られるビームラインは世界的にも極め て限られており, 実証実験は仏ラウエランジュバン研究所 の研究用原子炉で行われた。原子炉中性子源であるため, チョッパーを用いてパルス化されている．実証実験の後, この方法は改良が続けられた。単純に二つの六極磁石を回

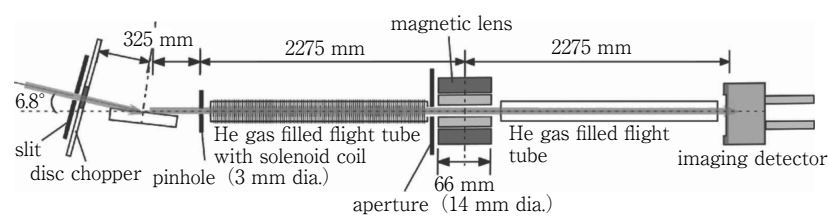

図 3 回転六極磁気レンズを用いたパルス極冷中性子小角散乱実証 実験のセットアップ
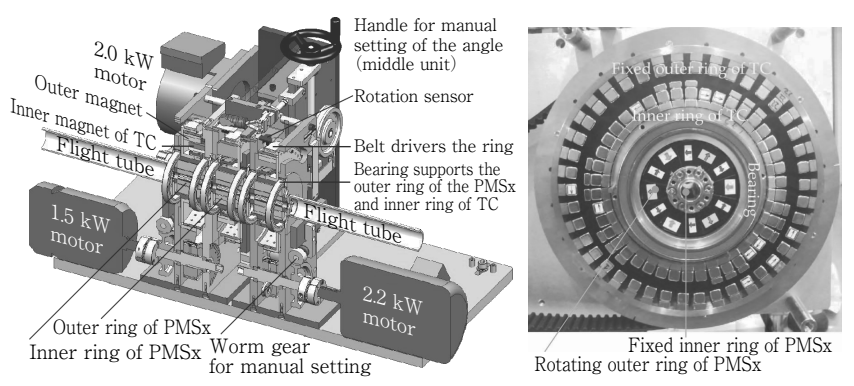

図 4 回転六極磁気レンズの構造図（左）と, 実物を軸方向から眺 めたときの写真（右）
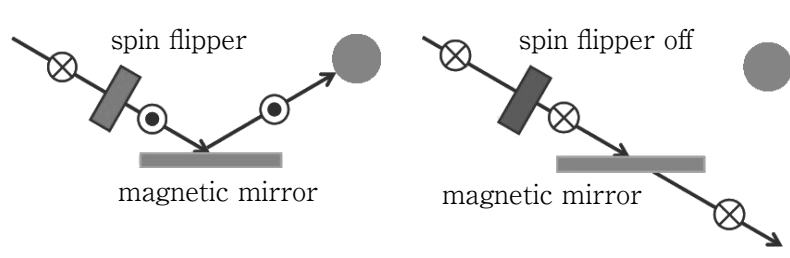

図５スピンフリップチョッパーの概念図

転させるだけだと，極めて大きなトルクが生じるために， 回転速度の制御が困難になる。そこで, さらに外側にトル クを相殺する磁石を配置して, 小さな回転トルクで回転を 制御できるような工夫がなされた。 そして集束力を高めて 焦点距離を短くするために, 三つの回転六極磁気レンズを 直列配置するという改良も加えられた，完成した回転六極 磁気レンズの構造と写真を図 4 に示す.

\section{5. スピンフリップチョッパー}

磁性体を用いた中性子スーパーミラーは, 中性子スピン の方向に応じて中性子を反射または透過させることができ る. また, 中性子スピンは交流磁場を用いて反転させるこ とができる。これらを組み合わせると，図５に示したよ うに, 偏極中性子ビームを電磁的に振り分けることが可能 である。このようなデバイスはスピンフリップチョッパー と呼ばれる。これによって高速にパルス中性子ビームを振 り分けて, 中性子ビームのバンチを生成することが可能で あり, 中性子の平均寿命測定に用いられている ${ }^{12)}$. 冷中性 子ビームのスピンフリップチョッパーを図 6 に示す. 各 磁気ミラーのスピン選択性は完全ではないため, 本来は出 力されるべきでないスピン成分が輸送され, 非出力時にも 中性子が出力されてしまう. 出力および非出力時の出力の コントラストを向上させるために, 多段式のビーム輸送系 が用いられている。 


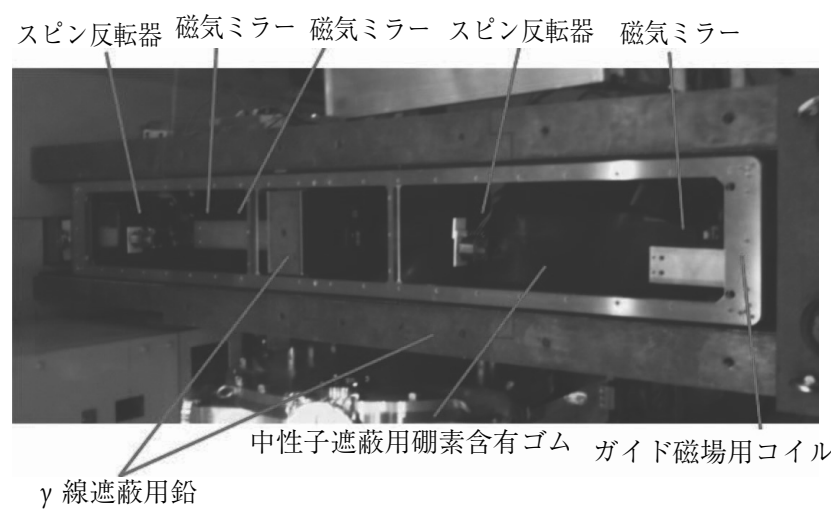

図 6 スピンフリップチョッパーを上から眺めた写真 ${ }^{13)}$. 偏極中性子 は左側から入射する

\section{6. 超冷中性子時間収束光学系}

超冷中性子は主に素粒子物理学の研究に用いられてお り, 高密度の超冷中性子蓄積が極めて重要な課題である. Liouvilleの定理によって位相空間密度が保存されるため, 高密度の超冷中性子を蓄積するには，発生時に大きな位相 空間密度を達成する必要がある。加速器中性子源を用いた 高密度超冷中性子源は世界各地で開発が続けられている。

中性子発生点での物理実験は困難なので，発生点から測 定点まで超冷中性子を移送する必要がある。単純に輸送す ると, 超冷中性子には速度に分布があるので, 空間密度が 減少する。しかし, 実際には位相空間密度は変化していな いので，位相空間分布が変形すれば空間密度を回復できる 場合がある，超冷中性子がパルス発生している場合がそれ に相当する。輸送中の各点に中性子が到達する時刻は中性子 速度に応じて異なるので，速い中性子を選択的に減速した り，遅い中性子を選択的に加速することが可能である。これ によって輸送先での空間密度を回復することができる ${ }^{14)}$.

ある磁場領域を通過するときに, 中性子はスピン方向に 応じて加減速されるが, 磁場を通過した後はもとの速度に 戻る。しかし磁場通過中にスピンが反転されると, もとの 速度に戻らない。図7のように勾配が制御された磁場を 用意しておく，その主磁場に対して垂直な方向に交流磁場 を印加する. 交流磁場の周波数が, 主磁場によるスピン歳 差周波数に等しい点を通過する際に，中性子スピンは反転 する.よって, 交流磁場の周波数を, 中性子が磁場領域に 到達する時刻に同期させて変化させると，中性子速度ごと に別々の速度変化を与えることができ, 中性子を時間的に 収束することができる。このようなデバイスは，中性子リ バンチャーとよばれる。 中性子リバンチャーによる時間収 束は，超冷中性子を用いて実証された ${ }^{15)}$ ，実験のセットア ップを図 8 に示す.

\section{7. ま と め}

中性子光学は, その要素となる個別の要素技術の高度化 が加速器科学, 原子力工学, 精密加工技術などの研究分野に 支えられて進む一方で，それらを複合させた制御技術への発
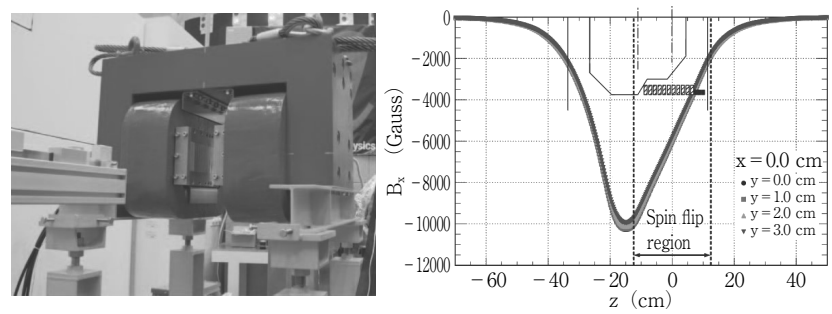

図 7 リバンチャー実証実験に用いられた電磁石の写真（左）と中 心軸上での磁場（右） ${ }^{16)}$

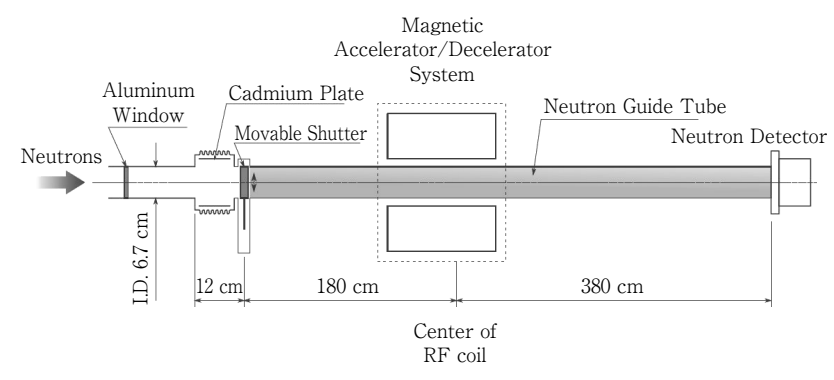

図 8

中性子リバンチャーによる時間収束実証実験のセットアップ15)

展が始まっており, 中性子の解析能力の底上げを支えてい る。そして，中性子利用技術の底上げは中小規模中性子源の 実用的利用につながってきており，大学や企業における新た な研究手法を提供することにもつながる可能性がある.

\section{参 考 文 献}

1) S.V. Grigoriev, A.I. Okorokov and V.V. Runov : Nucl. Instrum. Methods, A384 (1997) 451.

2) H.M. Shimizu et al. : Nucl. Instrum. Methods, A430 (1999) 423.

3) T. Oku et al. : Physica B, 385-386 (2006) 1225.

4) T. Shinohara et al. : Nucl. Instrum. Methods, A529 (2004) 134.

5) T. Oku et al. : Meas. Sci. Technol., 19 (2008) 034011.

6) S. Koizumi et al. : Physica B, 385-386 (2006) 1000.

7) H. Iwase et al. : J. Appl. Cryst., 44 (2011) 558.

8) T. Oku et al. : Nucl. Instrum. Methods, A600 (2009) 100.

9）山田雅子：パルス白色中性子ビーム集束のための強度変調型永 久六極磁石を用いた TOF レンズ, 京都大学大学院理学研究科物 理学第二専攻博士論文 2013 年.

10) M. Yamada et al. : Physica B, 404 (2009) 2646.

11) M. Yamada et al. : Physica B, 406 (2011) 2453.

12) K. Taketani et al. : Nucl. Instrum. Methods, A634 (2011) 134.

13) H. Otono: New Detector System for Precise Neutron Lifetime Measurement Using Pulsed Cold Neutron Beams, Dissertation for Ph. D. Thesis, Department of Physics, University of Tokyo, Dec. 2011.

14) H.M. Shimizu et al. : Nucl. Instrum. Methods, A634 (2011) 25.

15) Y. Arimoto et al. : Phys. Rev. A, 86 (2012) 023843.

16) Y. Arimoto et al. : Physics Procedia, 17 (2011) 20.

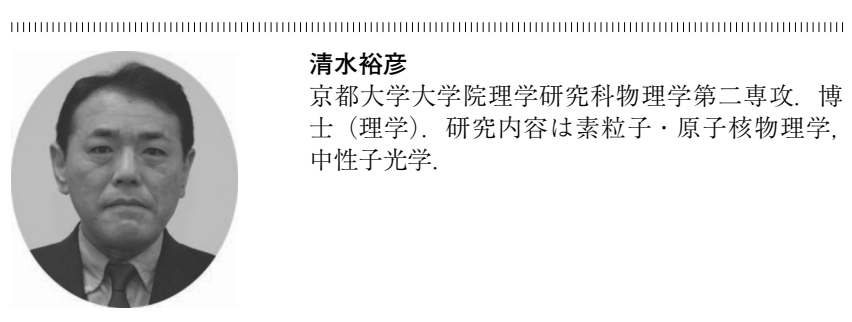

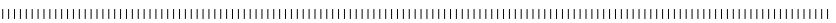

